\title{
Recurrence rates for neural tube defects and vitamin supplementation
}

\author{
WILLIAM H JAMES \\ From the Department of Genetics and Biometry, The Galton Laboratory, University College London, \\ 4 Stephenson Way, London NWI $2 H E$.
}

SUMmARY An attempt is made to assess the result of Smithells et al $^{\mathbf{1}}$ in the light of published data on recurrence rates for neural tube defects.

Smithells et $\mathrm{l}^{1}$ have offered data on an experiment in periconceptional vitamin supplementation in women known to be at high risk of producing an infant with neural tube defects. The women were ascertained by having already produced such an infant. Logically the best design for such an experiment would be to form matched pairs of such women and to give vitamins to one of each pair and placebos to the other. Not surprisingly, perhaps, ethical committees refused permission to administer placebos. So in practice some of the women (the S sample) were given the vitamins and others (the C sample) were given no treatment. Unfortunately, the women in the two groups were not matched and it turned out that a bigger proportion of the women in the $\mathrm{C}$ sample lived in low risk areas. There was a highly significant difference between the proportions of affected babies in the two samples. The question arises whether the difference might reasonably be supposed to have arisen through the admitted imperfection in experimental design.

There are several reasons for trying to answer this question:

(1) It seems unlikely that the ethical committees will relax their ruling on the use of placebos. ${ }^{12}$ (In parenthesis it might be remarked that such sternness on the part of the committees would not greatly impede progress in this matter. The point of the placebo is to guarantee lack of bias in assessing the outcome and to eliminate any psychological 'placebo effect' of the treatment. However, no-one seriously supposes that there might be an appreciable placebo effect here, and little bias can creep into the assessment of whether an infant has ASB or not.)

(2) Even if the ethical committees do relax their ruling on the use of placebos, some individual practitioners will feel reluctant to prescribe them

Received for publication 10 June 1980 especially in the deliberate randomised manner which seems the antithesis of compassion yet which is dictated by the logic underlying controlled trials. So 'properly controlled' trials may not become available on the point anyway.

(3) If it is not answered, it seems likely that methodological purists will reiterate the unhelpful suggestion that nothing scientifically worthwhile can emerge from a trial which is not 'properly controlled' and that therefore the results of Smithells et al ${ }^{1}$ can be safely dismissed.

Smithells and Sheppard ${ }^{2}$ offer a welcome to studies to assist in the interpretation of their data. Accordingly $I$ have assembled in table 1 all the data known to me on prevalence rates and recurrence rates of anencephaly and spina bifida (treated as a single entity). The purpose is to try to estimate the number of affected 'expected' in the S sample (expectation being based on the null hypothesis that periconceptional vitamins have no effect).

There are several points to note about the figures.

(1) It is clear that in those places where there is a high prevalence rate, there is also a high recurrence rate. But the variation between the prevalence rates is greater than the variation between the recurrence rates (even though the latter are based on much smaller figures and therefore have much greater standard errors). It has been noted too that when prevalence rates show secular variation in one place, the recurrence rates also vary, but apparently in a correspondingly restricted way. ${ }^{3}$ This concomitant variation of prevalence and recurrence rates is roughly in conformity with Edwards's formulation for the case where there is a continuous range of liability, that is, $r=\sqrt{p}$ where $r$ is the recurrence rate and $p$ the population prevalence rate. ${ }^{4}$

(2) The usual figure cited for recurrence rates of anencephaly and spina bifida combined in this country is $5 \%$, and the table justifies this use. 
TABLE 1 Rates of anencephaly and spina bifida among sibs of probands affected by anencephaly or spina bifida

\begin{tabular}{|c|c|c|c|c|c|}
\hline Source & $\begin{array}{l}\text { Estimated } \\
\text { population } \\
\text { prevalence } \\
(\%)\end{array}$ & Place & Years & $N$ & $\begin{array}{l}\text { Estimated } \\
\text { rate in } \\
\text { sibs }(\%)\end{array}$ \\
\hline $\begin{array}{l}\text { Carter et al } 6 \\
\text { Richards }\end{array}$ & 0.77 & South Wales & $1956-62$ & 81 & $5 \cdot 2$ \\
\hline et $a^{7}$ & 0.56 & Glasgow & 1964-68 & 51 & $5 \cdot 6$ \\
\hline Williamson 8 & 0.52 & Southampton & $1958-62$ & 9 & $5 \cdot 6$ \\
\hline $\begin{array}{l}\text { Czeizel and } \\
\text { Revesz } \\
\text { Carter and }\end{array}$ & 0.295 & Budapest & $1963-67$ & 16 & $3 \cdot 1$ \\
\hline $\begin{array}{l}\text { Evans } 10 \\
\text { Yen and }\end{array}$ & 0.29 & London & $1965-68$ & 66 & $4 \cdot 45$ \\
\hline $\begin{array}{l}\text { MacMahon } 3 \\
\text { McBride } 12\end{array}$ & $\begin{array}{l}30 \cdot 15-0.55 \\
0 \cdot 155\end{array}$ & $\begin{array}{l}\text { Rhode Island } \\
\text { British }\end{array}$ & $1936-65$ & 58 & $3 \cdot 3-8 \cdot 6$ \\
\hline $\begin{array}{l}\text { Naggan } 13 \\
\text { Janerich and }\end{array}$ & $0 \cdot 146$ & $\begin{array}{l}\text { Columbia } \\
\text { Israel }\end{array}$ & $\begin{array}{l}1952-70 \\
1958-68\end{array}$ & $\begin{array}{l}47 \\
24\end{array}$ & $\begin{array}{l}2 \cdot 4 \\
1 \cdot 34\end{array}$ \\
\hline Piper ${ }^{14}$ & $0 \cdot 13$ & $\begin{array}{l}\text { Upstate } \\
\text { New York }\end{array}$ & $1955-74$ & 22 & $2 \cdot 1$ \\
\hline
\end{tabular}

$\mathrm{N}$ is the number of affected sibs.

Seviral other sets of data have not been included in table 1 for the following reasons:

(1) Penrose 15 provided data from which recurrence rates can be estimated, but gave no comparable prevalence rate.

(2) Fedrick 16 estimated the rate of neural tube defect in sibs of probands with anencephaly only (none of her probands had spina bifida). Her estimate of this rate $(9.6 \%)$ seems remarkably high for an estimated prevalence of anencephaly alone of 1.49 per 1000 births in the Oxford Record Linkage Study Area.

(3) Smithells and co-authors ${ }^{17}$ estimated that $4 \cdot 3 \%$ of sibs of NTD probands were affected by NTD in Liverpool 1960-66. Their published estimates of prevalence rates are for rather different years (anencephaly 3.27 per 1000 during $1960-62,18$ and spina bifida 3.5 per 1000 during $1960-63,19$ totalling 6.77 per 1000 ).

(4) Record and McKeown20 estimated that the prevalence of NTD in Birmingham 1940-47 was 4.98 per 1000 births. Elsewhere, they offer figures 21 from which one would estimate that $1.8 \%$ of the sibs of their NTD probands were similarly affected. However, this latter figure seems to require a downward adjustment 22 and Elwood and Elwood ${ }^{23}$ suggest that Record and McKeown's material suffers from a considerable degree of underascertainment.

(5) Nevin and Johnston 24 estimate that $8.9 \%$ of sibs of probands with anencephaly or spina bifida are also affected in a population in which the prevalence is estimated at 8.7 per 1000 total births. I should like to suggest that this $8.9 \%$ is rather too high.

The authors note that parents of index patients were visited in order to obtain family histories. However, because of family migration, only $63 \%$ of the families were traced. This would not matter much if the families traced were representative of the untraced ones. There is some doubt on this point though. Of the sibships with a spina bifida index case, $72 \%$ were traced, whereas of those with an anencephalic index case, only $53 \%$ were traced $\left(x^{2}=14 \cdot 3, p<0.0002\right)$. It seems reasonable to suggest that family mobility is diminished (and tracing facilitated) by the presence of a living malformed child. If this were so, then the traced sibships will contain an unrepresentative number in which the sibs of the index case suffer from spina bifida.

(6) Cowchock et al 25 estimate a recurrence rate of $3 \%$ in an undefined population for which they suggest a prevalence rate of 1 to 2 per 1000.

However in calculating expectations based on the null hypothesis (that periconceptional vitamins have no effect) there are several reasons for wondering whether this value is applicable to the $\mathbf{S}$ sample of Smithells et al. ${ }^{1}$

(1) As mentioned above, a higher proportion of the $\mathrm{S}$ sample (as contrasted with the $\mathrm{C}$ sample) lived in low risk areas. It seems, though, if the figures in table 1 may be trusted, that in the UK the recurrence $\stackrel{5}{?}$ rates are not much lower in the low risk areas than $\overline{0}$ the high risk areas.

(2) The figures in table 1 refer to the probability $\frac{\bar{\sigma}}{2}$ that the sib of an affected case will also be affected. $\frac{\mathbb{Q}}{\circ}$ However, in the study sample, the relevant probability is that a later sib will be affected. In this context attention must be paid to birth order (or maternal $\vec{\circ}$ age) effects and to secular trends.

I have cited some, and presented other, evidence $\stackrel{\vec{\omega}}{\circ}$ that in anencephaly and spina bifida there is a $\overline{3}$ negative birth order (or maternal age) effect. ${ }^{5}$. However, opinion on the point is not unanimous and, $\vec{\infty}$ in any case, any decline in liability (consequent on changes in birth order or maternal age) between the index sib and the study sib in the data of Smithells et al $^{1}$ cannot have been very substantial.

Table 2 gives data for England and Wales for recent years on rates of notified congenital malformations of the CNS (of which neural tube defects form the major part), and rates of registered still- $\cong$ births plus infant deaths because of anencephaly. $\vec{\oplus}$ It will be seen that there has been a substantial $\stackrel{\infty}{-}$ decline in these rates. However, this decline is in rates at term: the monitoring of AFP levels (and subsequent selective abortion of affected fetuses) must have partially contributed to this.

Bradshaw et $a^{26}$ considered this decline and $\frac{\varnothing}{\varnothing}$ concluded that it is almost all the result of a decline in high risk births and AFP monitoring. In other words, there has been no appreciable decline in the rates of formation of the malformations when appropriate controls are applied. So secular trends may be ignored in the present considerations.

(3) The prevalence and recurrence rates in table $1 \stackrel{0}{\circ}$ are based on cases born at or around term. In 3 contrast, Smithells et $a l^{1}$ made their count of cases $\dot{\delta}$ well before term. So to be applicable to the $\mathrm{S}$ sample of Smithells et al, the recurrence rates in that table would accordingly have to be adjusted upwards to

TABLE 2 Rates of notified congenital malformations of the central nervous system (column a) and of registered stillbirths plus infant deaths from anencephaly (column b), England and Wales

\begin{tabular}{|c|c|c|}
\hline & $a$ & $b$ \\
\hline $\begin{array}{l}1973 \\
1974 \\
1975 \\
1976 \\
1977 \\
1978 \\
1979 \text { (1st quarter) }\end{array}$ & $\begin{array}{l}3 \cdot 73 \\
3 \cdot 79 \\
3 \cdot 65 \\
3 \cdot 25 \\
3 \cdot 25 \\
2 \cdot 92 \\
2 \cdot 67\end{array}$ & $\begin{array}{l}1 \cdot 63 \\
1 \cdot 52 \\
1 \cdot 34 \\
1 \cdot 23\end{array}$ \\
\hline
\end{tabular}

Sources: OPCS Birth Statistics

OPCS Monitor MB 3 79/4 
TABLE 3 Significance levels (a), critical Poisson expectations $(b)$, and corresponding 'expected' recurrence rates for the study of Smithells et al (c)

\begin{tabular}{llllll}
\hline (a) & 0.05 & 0.02 & 0.01 & 0.005 & 0.001 \\
(b) & 4.8 & 5.8 & 6.6 & 7.5 & 9.2 \\
(c) & 0.026 & 0.031 & 0.036 & 0.041 & 0.05 \\
\hline
\end{tabular}

compensate for those cases which would have aborted spontaneously before term but after that gestational stage at which counts were made in the study of Smithells et al.

In brief, to derive (or guess) a recurrence rate 'expected' on the null hypothesis for the $\mathrm{S}$ sample of Smithells et al from data in table 1, we must adjust downwards slightly for birth order and upwards for the inclusion of spontaneous abortions. It seems reasonable to suggest that these adjustments might roughly cancel out, and that, to be applicable to the $\mathrm{S}$ sample, the rate of $5 \%$ in the $\mathrm{C}$ sample has only to be adjusted for the geographical variation between the two samples. As remarked above, such an adjustment would seem to be rather slight in view of the figures in table 1 .

Table 3 gives the critical Poisson expectations for 1 or 0 observed cases among 185 pregnancies at risk, which are significant at varying levels, and the recurrence rates which correspond to each. So if one judged that the recurrence rate (expected on the null hypothesis) were $2.6 \%$ or more, the result of Smithells et al is significant at the 0.05 level. If one judged it to be $4 \%$ or more, one would take the result to be significant at the 0.01 level.

It is, of course, a matter of subjective judgment to assess the various adjustments indicated above, but it would seem to me unduly cautious to deny to the result of Smithells et al credence of an order appropriate to the $0 \cdot 05$ level.

Part of this work was done while the author was supported by the National Fund for Research into Crippling Diseases.

\section{References}

1 Smithells RW, Sheppard S, Schorah CJ, et al. Possible prevention of neural tube defects by periconceptional vitamin supplementation. Lancet $1980 ; \mathbf{i}: 339-40$.

1a Anon. Vitamins, neural tube defects and ethics committees. Lancet $1980 ; \mathrm{i}: 1061-2$.

2 Smithells RW, Sheppard S. Possible prevention of neural tube defects by periconceptional vitamin supplementation. Lancet $1980 ; \mathrm{i}: 647$.

3 Yen S, MacMahon B. Genetics of anencephaly and spina bifida? Lancet 1968 :ii :623-6.
4 Edwards JH. The simulation of Mendelism. Acta Genet 1960;10:63-70.

5 James WH. Birth ranks of spontaneous abortions in sibships of children affected by anencephaly or spina bifida. Br Med J 1978;i:72-3.

6 Carter CO, David PA, Laurence KM. A family study of major central nervous system malformations in South Wales. J Med Genet 1968;5:81-106.

7 Richards IDG, McIntosh HT, Sweenie S. A genetic study of anencephaly and spina bifida in Glasgow. Dev Med Child Neurol 1972;14:626-39.

8 Williamson EM. Incidence and family aggregation of major congenital malformations of the central nervous system. J Med Genet 1965;2:161-72.

9 Czeizel A, Revesz C. Major malformations of the central nervous system in Hungary. Br J Prev Soc Med 1970;24: 205-22.

10 Carter CO, Evans K. Spina bifida and anencephalus in Greater London. J Med Genet 1973;10:209-34.

12 McBride ML. Sib risks of anencephaly and spina bifida in British Columbia. Am J Med Genet 1979;3:377-87.

13 Naggan L. Anencephaly and spina bifida in Israel. Pediatrics $1971 ; 47: 577-86$.

14 Janerich DT, Piper J. Shifting genetic patterns in anencephaly and spina bifida. J Med Genet $1978 ; 15: 101-5$.

15 Penrose LS. Familial data on 144 cases of anencephaly, spina bifida and congenital hydrocephaly. Ann Eugen 1946;13:73-96.

16 Fedrick J. Anencephalus in the Oxford Record Linkage Study Area. Dev Med Child Neurol 1976;18:643-56.

17 Smithells RW, D'Arcy EE, McAllister EF. The outcome of pregnancies before and after the birth of infants with nervous system malformations. Dev Med Child Neurol (Suppl) 1968;15:6-10.

18 Smithells RW, Chinn ER, Franklin D. Anencephaly in Liverpool. Dev Med Child Neurol 1964;6:231-40.

19 Smithells RW, Chinn ER. Spina bifida in Liverpool. Dev Med Child Neurol 1965;7:258-68.

20 Record RG, McKeown T. Congenital malformations of the CNS. I. A survey of 930 cases. Br J Soc Med 1949;3: 183-219.

21 Record RG, McKeown T. Congenital malformations of the CNS. II. Maternal reproductive history and familial incidence. Br J Soc Med 1950;4:26-50.

22 Record RG, McKeown T. Congenital malformations of the CNS. III. Risk of malformation in sibs of malformed individuals. $\mathrm{Br} J$ Soc $\mathrm{Med} 1950 ; 4: 217-20$.

23 Elwood JM, Elwood JH. Epidemiology of anencephalus and spina bifida. Oxford: Oxford University Press, 1980: 225.

24 Nevin NC, Johnston WP. A family study of spina bifida and anencephalus in Belfast, Northern Ireland (1964 1968). J Med Genet 1980;17:203-11.

25 Cowchock S, Ainbender E, Prescott G, et al. The recurrence risk for neural tube defects in the US: a collaborative study. Am J Med Genet 1980;5:309-14.

26 Bradshaw J, Weale J, Weatherall JAC. Congenital malformations of the central nervous system. Population Trends 1980;19:13-8.

Requests for reprints to Dr W H James, Department of Genetics and Biometry, The Galton Laboratory, University College London, 4 Stephenson Way, London NW1 2HE. 